\title{
Analisis Determinan Ketepatan Waktu Pelaporan Keuangan Perusahaan Manufaktur
}

\author{
Adila Ayu Sukma ${ }^{1}$, Sartika Wulandari ${ }^{2}$, dan Widhian Hardiyanti ${ }^{3}$ \\ ${ }^{1}$ Universitas Stikubank Semarang \\ adilla.ayu.s@gmail.com \\ ${ }^{2}$ Universitas Stikubank Semarang \\ sartika_wulan@edu,unisbank.ac.id \\ ${ }^{3}$ Universitas Stikubank Semarang \\ widhian@edu.unisbank.ac.id
}

\section{ARTICLE INFO}

Article history:

Received 30 September 2021

Received in revised form 2 November 2021

Accepted 10 November 2021

Available online 1 Desember 2021
This study examines the effect of managerial ownership, institutional ownership, independent commissioners, audit committees and profitability, on the timeliness of financial reporting in manufacturing companies listed on the Indonesia Stock Exchange for the 2016-2019 period. The population in this study were all companies listed on the Indonesia Stock Exchange from 2016 to 2019. The sample selection used the purposive sampling method and 299 samples were obtained. The analysis used is logistic regression analysis. The results showed that profitability had a significant positive effect on the timeliness of financial reporting. Meanwhile, managerial ownership, institutional ownership, independent commissioners, and audit committees have no effect on the timeliness of financial reporting.

Keywords: Timeliness, corporate governance, profitability.

\section{ABSTRACT}

\section{PENDAHULUAN}

Informasi menjadi salah satu faktor penentu dalam pengambilan keputusan. Informasi yang dibutuhkan dapat berupa informasi akuntansi dan informasi keuangan lain. Informasi keuangan ini harus tersedia untuk pengguna dalam waktu singkat yang diatur setelah akhir keuangan tahun. Mengingat pentingnya informasi perusahaan dalam pengambilan keputusan maka ketepatan waktu pelaporan memegang peranan tinggi dan berharga bagi pihak-pihak yang membutuhkan [1], [2]. Laporan keuangan harus tersedia sebelum kehilangan kemampuannya untuk mempengaruhi para pengambil keputusan [2].

Laporan keuangan merupakan bagian dari proses pelaporan keuangan. Ketepatan waktu pelaporan keuangan adalah karakteristik kualitatif yang diperlukan dari informasi keuangan yang relevan dan dengan demikian menerima peningkatan perhatian dari regulator akuntansi dan otoritas pencatatan di seluruh dunia [2]. Laporan keuangan yang perusahaan harus disampaikan tepat waktu dan informasi keuangan yang lengkap meliputi laporan laba-rugi, laporan ekuitas, laporan perubahaan posisi keuangan, laporan arus kas dan catatan atas laporan keuangan. Laporan keuangan merupakan hal yang sangat penting untuk memberikan informasi perusahaan untuk 
kepentingan pihak-pihak diluar perusahan salah satunya: pemegang saham atau investor serta pihak-pihak lainnya [3].

Informasi laporan keuangan sangat bermanfaat untuk pengambilan keputusan harus merupakan informasi yang relevan dan reliabilitas. Laporan keuangan akan terlihat jelas apabila pihak internal perusahaan menyampaikan laporan secara jelas. Sehingga laporan keuangan harus dilaporkan secara tepat waktu dikarenakan akan sangat penting bagi investor sebagai dasar pengambilan keputusan dalam berinvestasi atau menarik kembali modal yang telah diinvestasikan [4]. Untuk meningkatkan ketepatan waktu pelaporan keuangan, perusahaan dan dewan direksi harus mempertimbangkan latar belakang dan keahlian akuntansi anggota komite audit potensial dan ketua komite audit [5].

Faktor-faktor yang berpengaruh terhadap ketepatan waktu pelaporan keuangan yang akan diuji dari penelitian ini yaitu: Kepemilikan Menejerial, Kepemilikan Institusional, Komisaris Independen, Komite Audit dan Profitabilitas. Kepemilikan manajerial merupakan kepemilikan saham oleh pihak manajemen perusahaan. Kepemilikan saham manajerial dapat mensejajarkan antara kepentingan pemegang saham dengan manajer, karenan manajer ikut merasakan langsung manfaat dari keputusan yang diambil dan manajer ikut merasakan langsung manfaat dari keputusan yang diambil dan manajer yang menanggung risiko apabila ada kerugian yang timbul sebagai konsekuensi dari pengambilan keputusan yang salah. Semakin besar proporsi kepemilikan manajemen pada perusahaan akan dapat menyatukan kepentingan antara manajer dengan pemegang saham. Kepemilikan manajerial memberikan kesempatan manajer terlibat dalam kepemilikan saham sehingga dengan keterlibatan ini kedudukan manajer sejajar dengan pemegang saham. Manajer diperlukan bukan semata sebagai pihak eksternal yang digaji untuk kepentingan perusahaan tetapi diperlukan sebagai pemegang saham. Sehingga diharapkan adanya keterlibatan manajer pada kepemilikan saham dapat efektif untuk meningkatkan kinerja manajer[6]. Berdasarkan penelitian yang dilakukan oleh [6], [7]mmenunjukkan, bahwa kepemilikan manajerial berpengaruh positif signifikan terhadap ketepatan waktu pelaporan keuangan dibandingkan dengan [8] bahwa kepemilikan menejerial negatif tidak berpengaruh terhadap ketepatan waktu pelaporan keuangan.

Kepemilikan Institusional merupakan kepemilikan saham perusahaan oleh suatu lembaga atau institusi baik bergerak dalam bidang keuangan maupun non keuangan seperti reksa dana, asuransi, dana pension, perbankan dan institusi lainnya. Kepemilikan Institusional memiliki hak untuk menuntut dan mewajibkan pihak menejemen untuk segera menyampaikan laporan keuangannya lebih tepat waktu [9]. Penelitian yang dilakukan oleh [6]menunjukkan,bahwa kepemilikan institusional berpengaruh signifikan terhadap ketepatan waktu pelaporan keuangan dibandingkan dengan [8], [9] tidak berpengaruh terhadap ketepatan waktu pelaporan keuangan.

Komisaris independen merupakn prosentase anggota komisaris perusahaan yang berasal dari pihak luar. keberadaan komisaris independen merupakan pengendalian internal perusahaan akan membuat menejem unutk segera menyampaikan laporan keuangan sehingga akan meningkatkan kualitas laporan keuangan. Adanya komisaris independent dengan keahlian yang tepat dan yang tidak memiliki hubungan istimewa dengan perusahaan, ada dalam posisi yang lebih baik untuk memastikan bahwa kepentingan pemegang saham dilindungi dan untuk memastikan bahwa laporan keuangan yang dibuat tersedia untuk membantu pengambilan keputusan [1]. Keberadaan komisaris independen juga berfungsi untuk monitoring terhadap pihak perusahaan agar bekerja lebih baik[6]. Hal ini sesuai dengan penelitian yang dilakukan oleh [6], [7], bahwa komisaris independen berpengaruh terhadap ketepatan waktu pelaporan keuangan. Namun hasil ini tidak sejalan dengan [8] bahwa komisaris independen tidak berpengaruh terhadap ketepatan waktu pelaporan keuangan.

Komite audit memiliki tanggung jawab dalam memonitor dan mengawasi audit laporan keuangan dan memastikan agar standar kebijakan keuangan telah terpenuhi, memeriksa ulang laporan keuangan apakah sudah sesuai dengan standard dan kebijaksanaan sehingga pihak menjemen akan segera menyampaikan laporan keuanganya tepat waktu. Pembentukan komite

JURNAL ILMIAH KOMPUTERISASI AKUNTANSI Vol. 14, No. 2, Desember 2021 : 265 - 274 
audit merupakan salah satu wujud untuk memperbaiki kinerja internal perusahaan, komite audit yang efektif adalah sebagai alat untuk meningkatkan keefektifan, tanggung jawab,keterbukaan dan obyektifitas dewan komisaris [10]. Komite audit yang efektif akan membantu auditor eksternal mengurangi lag pelaporan dan meningkatkan ketepatan waktu pelaporan keuangan [11]. Ketua komite audit yang memiliki keahlian dan pengalaman dalam pemantauan, akan lebih efektif dalam membatasi keterlambatan laporan audit dan, karenanya, meningkatkan ketepatan waktu pelaporan keuangan [12]. Berdasarkan penelitian yang dilakukan oleh [13], bahwa komite audit berpengaruh positif terhadap ketepatan waktu pelaporan. Akan tetapi hasil ini tidak sejalan dengan [8] yang menyatakan komite audit tidak berpengaruh secara signifikan terhadap ketepatan waktu pelaporan keuangan.

Profitabilitas merupakan kemampuan perusahaan memperoleh laba dalam satu periode akuntansi setelah dibandingkan dengan total aset maupun modal sendiri. Semakin tinggi profitabilitas maka perusahaan tersebut memiliki kinerja yang baik, sehingga tingkat kemampuan perusahaan menghasilkan keuntungan yang dilaporkan, diperkirakan dapat mempengaruhi tepat atau tidaknya waktu penyajian laporan keuangan kepada publik [14]. Penelitian yang dilakukan [15][14], menunjukkan bahwa profitabilitas berpengaruh positif terhadap ketepatan waktu pelaporan keuangan.

Namun penelitian yang dilakukan oleh [16] bahwa Profitabilitas tidak berpengaruh terhadap ketepatan waktu pelaporan keuangan. Tujuan dari penelitian ini adalah menguji dan menganalisis pengaruh good coorporate governance dan profitabilitas terhadap ketepatan waktu pelaporan keuangan.

\section{Metode Penelitian}

\subsection{Populasi dan Sampel}

Populasi dalam penelitian ini adalah perusahaan manufaktur yang terdaftar di BEI periode 20162019 dikarenakan perusahaan manufaktur memiliki cakupan yang luas. Sampel merupakan bagian dari jumlah dan karakteristik populasi. Teknik pengambilan sampel yang digunakan adalah teknik purposive sampling. Teknik ini adalah penentuan sampel dengan pertimbangan tertentu adapun teknik yang ditentukan adalah: perusahaan manufaktur yang menerbitkan laporan tahunan tahun 2016-2019; perusahaan manufaktur yang menyediakan semua data yang dibutuhkan mengenai kepemilikan manajerial, kepemilikan institusional, komisaris.

\subsection{Hipotesis}

H1: Kepemilikan Managerial berpengaruh positif terhadap ketepatan waktu Pelaporan Keuangan H2:Kepemilikan Institusional berpengaruh positif terhadap ketepatan waktu Pelaporan Keuangan H3:Komisaris Independen berpengaruh positif terhadap ketepatan waktu Pelaporan Keuangan H4:Komite Audit berpengaruh positif terhadap ketepatan waktu Pelaporan Keuangan H5:Profitabilitas berpengaruh positif terhadap ketepatan waktu Pelaporan Keuangan

\subsection{Pengukuran Variabel}

Penelitian ini terdiri dari dua variabel yaitu variabel dependen dan variabel independen. Variabel Independen terdiri dari Kepemilikan Manajerial, Kepemilikan Institusional, Komisaris Independen, Komite Audit, Profitabilitas, sedangkan variabel dependen yaitu: Ketepatan Waktu Pelaporan Keuangan.

Tabel 1. Pengukuran Variabel

\begin{tabular}{|c|c|l|}
\hline No & Variabel & Pengukuran \\
\hline 1. & $\begin{array}{c}\text { Ketepatan Waktu pelaporan } \\
\text { Keuangan }\end{array}$ & Tepat Waktu= dummy 1 \\
& Tidak tepat Waktu= dummy 0 \\
\hline
\end{tabular}

Analisis Determinan Ketepatan Waktu Pelaporan Keuangan Perusahaan Manufaktur (Adila Ayu 


\begin{tabular}{|c|c|c|}
\hline 2. & Kepemilikan Managerial & $K M=\frac{\text { Saham Managerial }}{\text { Saham Beredar }}$ \\
\hline 3. & Kepemilikan Instituional & INST $=\frac{\text { Saham Institusional }}{\text { Saham Beredar }}$ \\
\hline 4. & Komisaris Independen & $K I=\frac{\text { Komisaris Independen }}{\text { Anggota } \text { Komisaris }}$ \\
\hline 5. & Komite Audit & Jumlah Anggota Komite Audit \\
\hline 6. & Profitabilitas & ROA $=\frac{\text { Laba Bersih }}{\text { Total Aset }}$ \\
\hline
\end{tabular}

\section{Hasil Penelitian Dan Pembahasan}

Populasi dalam penelitian ini adalah perusahaan manufaktur yang terdaftar di Bursa Efek Indonesia (BEI) pada tahun 2016 sampai dengan tahun 2019. Jumlah populasi dalam penelitian ini yaitu 634 perusahaan manufaktur yang terdaftar di Bursa Efek Indonesia, dan ada 299 perusahaan yang termasuk dalam kriteria sampel.

Tabel 2

Statistik Deskriptif

\begin{tabular}{|l|r|r|r|r|r|}
\hline & $\mathrm{N}$ & \multicolumn{1}{|c|}{ Minimum } & Maximum & \multicolumn{1}{c|}{ Mean } & Std. Deviation \\
\hline KW & 299 &, 0 & 1,0 &, 806 &, 3961 \\
$\mathrm{KM}$ & 299 &, 00000246 &, 98373066 &, 1288805481 &, 19458109992 \\
$\mathrm{KINS}$ & 299 &, 01626934 & 1,19574972 &, 6288687214 &, 22689704532 \\
$\mathrm{KI}$ & 299 &, 12500000 &, 66666667 &, 3857156129 &, 08512333261 \\
$\mathrm{KA}$ & 299 & 1,0 & 5,0 & 3,064 &, 3745 \\
ROA & 299 &,- 43044485 &, 25749923 &, 0300096365 &, 07281965302 \\
Valid N (listwise) & 299 & & & & \\
\hline
\end{tabular}

Sumber : data olahan

Tabel 2 adalah hasil output pengujian statistika deskriptif untuk menggambarkan variabelvariabel yang digunakan dalam penelitian. Minimum adalah nilai terkecil dari suatu rangkaian pengamatan, maksimum sendiri merupakan nilai terbesar dari suatu rangkaian pengamatan, ratarata (mean) merupakan nilai hasil penjumlahan seluruh data dibagi dengan banyaknya data dan standar deviasi adalah akar dari jumlah kuadrat selisih nilai data dengan rata-rata dibagi dengan banyaknya data.

Tabel 2 diatas menunjukan bahwa jumlah sampel (N) yang diteliti sebanyak yang diteliti sebanyak 299 perusahaan Manufaktur yang terdaftar di Bursa Efek Indonesia (BEI) selama tahun 2016 sampai tahun 2019. Kepemilikan manajerial dihitung dengan membagi saham manajerial dengan saham beredar dikali 100\% selama tahun 2016-2019. Nilai rata - rata sebesar 0,1288805481 , nilai standar deviasi sebesar 0,19458109992. Nilai minimum kepemilikan manajerial selama tahun 2016-2019 sebesar 0,00000246, sedangkan nilai maksimum kepemilikan manajerial sebesar 0,98373066.

Kepemilikan institusional dihitung dengan membagi saham institusional dengan saham beredar dikali $100 \%$. Nilai rata-rata kepemilikan institusional selama tahun 2016-2019 sebesar 0,6288687214, nilai standar deviasi sebesar 0,2268970453. Nilai minimum kepemilikan institusional selama tahun 2016-2019 sebesar 0,01626934, sedangkan nilai maksimum kepemilikan institusional sebesar 1,19574972. Komisaris independen dihitung dengan membagi jumlah anggota yang berasal dari luar (independen) dengan jumlah anggota keseluruhan dikali

JURNAL ILMIAH KOMPUTERISASI AKUNTANSI Vol. 14, No. 2, Desember $2021: 265-274$ 
100\%. Nilai rata-rata komisaris independen selama tahun 2016-2019 sebesar 0,3857156129, nilai standar deviasi sebesar 0,0851233326. Nilai minimum komisaris independen selama tahun 20162019 sebesar 0,12500000, sedangkan nilai maksimum komisaris independen sebesar 0,66666667.

Komite audit dihitung dengan melihat jumlah anggota komite audit. Nilai rata-rata komite audit selama tahun 2016-2019 sebesar 3,064, nilai standar deviasi sebesar 0,3745. Nilai minimum komite audit selama tahun 2016-2019 sebesar 1, sedangkan nilai maksimum komite audit sebesar 5. Profitabilitas dihitung dengan membagi laba bersih tahun berjalan dengan jumlah aset dikali $100 \%$. Nilai rata-rata profitabilitas selama tahun 2016- 2019 sebesar 0, 0300096365, nilai standar deviasi sebesar 0, 07281965302. Nilai minimum profitabilitas selama tahun 2016-2019 sebesar 0, 43044485, sedangkan nilai maksimum profitabilitas sebesar 0, 25749923. Nilai ketepatan waktu pelaporan keuangan yang dapat waktu sebesar 241 perusahaan dengan persentase $80,6 \%$. Nilai ketepatan waktu pelaporan keuangan yang tidak tepat waktu sebesar 58 perusahaan dengan persentase 19,4\%. Dari total 299 perusahaan dengan total persentase $100 \%$.

\subsection{Menilai Kelayakan Model Regresi}

Pengujian kelayakan model regresi logistik dapat dilakukan dengan melihat goodness of fit test dengan nilai Chi Square. Jika nilai sig >0,05 maka hipotesis diterima dengan begitu data empiris sesuai dengan model, shingga model dikatakan fit. Namun jika nilai sig $<0,05$ maka hipotesis ditolak dikarenakan data empiris tidak sesuai dengan model.

\section{Tabel 3}

\begin{tabular}{|l|r|r|r|}
\hline Step & Chi-square & df & \multicolumn{1}{c|}{ Sig. } \\
\hline 1 & 7,912 & & 8 \\
\hline
\end{tabular}

Berdasarkan tabel diatas dapat diketahui output Hosmer and Lemeshow test menunjukan nilai Chi-square sebear 7,912 dengan tingkat signifikansi sebesar 0,442. Berdasarkan nilai signifikansi lebih dari 0,05 sehingga dapat disimpulkan bahwa model mampu memprediksi nilai observasinya atau dapat dikatakan model dapat diterima.

\subsection{Menilai Keseluruhan Model}

Pengujian ini dapat dilakukan dengan membandingkan nilai antara -2 log likelhood (-2LL) Blok Number $=0$ dengan -2 log likelhood $(-2 L L)$ Blok Number $=1$. Dengan perbandingan nilai antara -2LL awal dan -2LL akhir yang menurun menunjukan bahwa model dinyatakan fit dengan data.

Tabel 4

Goodness of Fit Test Blok 0

\begin{tabular}{|c|c|c|}
\hline \multirow[b]{2}{*}{ Iteration } & \multirow[b]{2}{*}{$\begin{array}{l}-2 \text { Log } \\
\text { likelihood }\end{array}$} & Coefficients \\
\hline & & Constant \\
\hline Step 1 & 296,134 & 1,224 \\
\hline 2 & 294,187 & 1,413 \\
\hline 3 & 294,182 & 1,424 \\
\hline 4 & 294,182 & 1,424 \\
\hline
\end{tabular}

Sumber : data olahan

Analisis Determinan Ketepatan Waktu Pelaporan Keuangan Perusahaan Manufaktur (Adila Ayu 
Tabel 5

Goodness of Fit Test Blok 1

\begin{tabular}{|c|c|c|}
\hline \multicolumn{2}{|l|}{ Iteration } & -2 Log likelihood \\
\hline Step 1 & 1 & 283,689 \\
\hline & 2 & 279,202 \\
\hline & 3 & 279,131 \\
\hline & 4 & 279,131 \\
\hline & 5 & 279,131 \\
\hline
\end{tabular}

Sumber : data olahan

Tabel 4 dan 5 diatas menunjukan uji kelayakan dengan melihat angka pada (-2LL) blok number $=0$ dan $(-2 L L)$ Blok number $=1$. Pada tabel diatas terlihat bahwa nilai $(-2 L L)$ blok number 0 sebesar 296,134 dan nilai (-2LL) blok number 1 sebesar 283,689. Dengan adanya penurunan nilai dari (-2LL) blok number 0 ke (- 2LL) blok number 1 dapat dikatakan model yang dihipotesiskan fit dengan data

Tabel diatas menunjukan overall model fit pada $-2 \mathrm{LL}$ blok number $=0$ menunjukan adanya penurunan pada -2 LL blok number $=1$. Apabila nilai -2 Log Value Blok Number 0 lebih besar dari -2 Log Value Blok Number 1, maka menunjukan model regresi yang baik, sehingga penurunan Log Likelhood model regresi semakin baik.

\subsection{Koefisien Determinan}

Tabel 6

Model Summary

\begin{tabular}{|l|r|r|r|}
\hline Step & -2 Log likelihood & $\begin{array}{c}\text { Cox \& Snell R } \\
\text { Square }\end{array}$ & $\begin{array}{c}\text { Nagelkerke } \\
\text { RSquare }\end{array}$ \\
\hline 1 & $279,131^{\mathrm{a}}$ &, 049 &, 078 \\
\hline
\end{tabular}

Sumber : data olahan

Tabel diatas menunjukan nilai Cox and Snell R Square sebesar 0,049 dan nilai Nagelkerke R Square sebesar 0,078. Yang menunjukan variabel ketepataan waktu dapat dijelaskan oleh kepemilikan manajerial, kepemilikan institusional, komisaris independen, komite audit, profitabilitas adalah sebesar 7,8\% sedangkan sisanya sebesar $92,2 \%$ di jelaskan oleh variabelvariabel di luar model penelitian.

\subsection{Pembahasan}

\subsubsection{Kepemilikan Manajerial terhadap Ketepatan Waktu Pepalopan Keuangan}

Hasil perhitungan statistika menunjukan kepemilikan manajerial memiliki nilai probabilitas sebesar 0,431, yang menandakan bahwa 0,431>0,05 hasil tersebut menandakan kepemilikan manjerial tidak berpengaruh terhadap ketepatan waktu pelaporan keuangan. Hal ini dikarenakan tidak semua perusahaan manufaktur memiliki saham manajerial dan presentase kepemilikan saham manajerial masih sangat kecil sebesar 0,0000246 dari tabel 4.2 . Hal ini tidak sesuai dengan teori agensi dimana kepemilikan manajerial yang efektif dapat menjadi mekanisme dalam mengatasi adanya asimetris informasi antara manajemen dengan pemegang saham. Perusahaan dengan kinerja yang baik tentu tidak akan menunda untuk menyampaikan laporan keuangannya kepada publik baik perusahaan dengan kepemilikan saham manajerial yang tinggi maupun rendah akan menyampaikan laporan keuanganya tepat waktu. Akan tetapi pada penelitian ini

JURNAL ILMIAH KOMPUTERISASI AKUNTANSI Vol. 14, No. 2, Desember $2021: 265-274$ 
perussahaan dengan kepemilikan manjerial yang semakin tinggi tiap tahunnya tidak selalu menyampaikan laporan keuanganya tepat waktu.

Hasil penelitian kepemilikan manajerial berpengaruh negatif tidak signifikan terhadap ketepatan waktu pelaporan keuangan, sejalan dengan penelitian yang dilakukan oleh [17] yang menyatakan perusahaan dengan kepemilikan menjerial baik yang tinggi maupun rendah tidak serta merta akan meningkatkan pihak menegement dalam menyampaikan laporan keuangannya lebih tepat waktu, sehingga dapat diartikan bahwa kepemilikan manajerial berpengaruh negatif tidak signifikan terhadap ketepatan waktu pelaporan keuangan.

\subsubsection{Kepemilikan Institusional terhadap Ketepatan Waktu Pepalopan Keuangan}

Hasil perhitungan statistika menunjukan kepemilikan institusional memiliki nilai probabilitas sebesar 0,750 , yang menandakan bahwa $0,750>0,05$ hasil penelitian ini menunjukan bahwa kepemilikan institusional tidak berpengaruh terhadap ketepatan waktu pelaporan keuangan. Tidak berpengaruhnya kepemilikan institusional tehadap ketepatan waktu pelporan diduga karena kurangnya pengawasan dari pihak institusi selaku pemegang saham dan pihak institusi lebih mementingkan laba dari pada waktu penyampaian laporan keuangan. Hal ini tidak sesuai dengan teori agensi dimana perusahaan dengan kepemilikan institusional yang besar akan menyampaikan laporan keuanganya tepat waktu pada dasarnya dengan kepemilakan institusional perusahaan yang besar maupun kecil akan menyampaikan laporan keuanganya tepat waktu dikarenakan akan mempengaruhi keputusan investor untuk mendanai dananya kembali.

Hasil penelitian ini bertentangan dengan [6] yang menunjukan kepemilikan instutisonal berpengaruh positif terhadap ketepatan waktu pelaporan keuangan, namun hasil ini sejalan [18] yang menunjukan kepemilikan institusional berpengaruh negatif tidak signifikan terhadap ketepatan waktu pelaporan keuangan. Hal ini menandakan tidak adanya hubungan yang signifikan antara kepemilikan pihak luar atau institusi dengan ketepatan waktu penyamapaian laporan keuangan.

\subsubsection{Komisaris Independen terhadap Ketepatan Waktu Pepalopan Keuangan}

Hasil perhitungan statistika menunjukan komisaris independen memiliki nilai probabilitas sebesar 0,264, yang menandakan bahwa 0,264 >0,05 hasil penelitian ini menunjukan komisaris independen tidak berpengaruh terhadap ketepatan waktu pelaporan keuangan. Komisaris independen merupakan organisasi perseroan yang memiliki tugas dalam pengawasan secara umum dan memberikan masukan kepada menegement perusahaan. Ketika komisaris independen memiliki tingkat pengawasan yang tinggi dalam penyusunan dan merancang laporan keuangan sehingga akan membuat keterlambatan penyampaian laporan. Hal ini tidak sesuai dengan teori agensi komisaris independen tidak dapat mempengaruhi manajemen perusahaan dalam menyampaikan laporan keuanganya lebih tepat waktu dimana bila tingkat komisaris independen yang tinggi maka ketepatan waktu pelaporan keuangan perusahaan akan lebih rendah.

Hasil penlitian ini bertentangan dengan [18] yang menyatakan komisaris independen memiliki pengaruh terhadap ketepatan waktu pelaporan keuangan komisaris independen diharapkan memberikan perhatian dalam menjalankan tugas dan kewajibannya sehingga mengharuskan peruahaan memberikan informasi yang lebih kepada investor. Namun hasil penelitian ini sejalan dengan [9] yang menyatakan komisaris independen berpengaruh negatif tidak signifikan terhadap ketepatan waktu pelaporan keuangan perussahaan

\subsubsection{Komite Audit terhadap Ketepatan Waktu Pepalopan Keuangan}

Hasil perhitungan statistika menunjukan komite audit memiliki nilai probabilitas sebesar 0,415 yang menandakan bahwa nilai probabilitas $0,415>0,05$ hasil tersebut menunjukan bahwa komite audit tidak berpengaruh terhadap ketepatan waktu pelaporan keuangan. Komite audit

Analisis Determinan Ketepatan Waktu Pelaporan Keuangan Perusahaan Manufaktur (Adila Ayu 
berkaitan dengan pengelolaan perusahaan dalam penyusunan laporan keuangan sesuai dengan peraturan yang berlaku. Komite audit memiliki tugas yang berhubungan langsung dengan permasalahan akuntansi suatu perusahaan, pengawasan internal dan sistem pelaporan keuangan sehingga belum mampu mendorong pihak manajemen untuk menyampikan laporan keuangannya tepat waktu. Hal ini tidak sesuai dengan teori agensi dimana komite audit tidak berpengaruh terhadap penyampaian laporan keuangan dikarenakan fungsi komite audit adalah sebagai pengawas independen pihak internal dan eksternal pada perusahaan.

Hasil penelitian komite audit berpengaruh positif tidak signifikan terhadap ketepatan waktu pelaporan keuangan sejalan dengan penelitian yang dilakukan oleh [6], [8], [13] berhasil membuktikan tidak berpengaruhnya komite audit terhadap ketepatan waktu pelaporan keuangan. Penelitian ini menunjukan bahwa ukuran komite audit bukan faktor penentu efektivitas komite audit. Komite audit merupakan buatan manajemen yang berfungsi membantu dewan komisaris dan patuh terhadap manajemen bukan sebagai pengawas seperti yang diharapkan pemegang saham (principal).

\subsubsection{Profitabilitas terhadap Ketepatan Waktu Pepalopan Keuangan}

Hasil perhitungan statistika menunjukan profitabilitas memiliki nilai signifikansi sebesar 0,001 yang menandakan bahwa nilai signifikansi 0,001 >0,05 Hasil pengujian hipotesis dapat diketahui bahwa profitabiltas berpengaruh terhadap ketepatan waktu pelaporan keuangan. Perusahaan dengan profit tinggi menandakan perusahaan tersebut mampu mengelola sumber dayanya dengan baik dan memberikan deviden yang tinggi ke investor. Hal ini sesuai dengan teori sinyal, perusahaan dengan profitabilitas yang tinggi akan menayampaikan laporan keuanganya tepat waktu sehingga akan membawa kabar baik (good news) kepada investor yang mendanai dananya.

Hasil penelitian profitabilitas berpengaruh positif signifikan terhadap ketepatan waktu pelaporan keuangan sejalan dengan penelitian yang dilakukan oleh [9] dan [16] yang menyatakan perusahaan dengan tingkat profitabilitas yang tinggi akan memberikan kabar baik kepada investor untuk mendanai dananya kembali yang berarti bahwa Profitabilitas berpengaruh positif signifikan terhadap ketepatan waktu pelaporan keuangan.

\section{Simpulan}

Berdasarkan pada data yang dilakukan pengujian dan telah dilakukan pengujian model regresi logistik, variabel kepemilikan manajerial, kepemilikan institusional, komisaris independen, komite audit dan profitabilitas terhadap ketepatan waktu pelaporan keuangan pada perusahaan manufaktur yang terdaftar di Bursa Efek Indonesia tahun 2016-2019, dapat disimpulkan bahwa: kepemilikan manajerial, kepemilikan kepemilikan institusional, komisaris independen, dan komite audit tidak berpengaruh secara signifikan terhadap ketepatan waktu pelaporan keuangan. Sedangkan profitablitas berpengaruh positif signifikan terhadap ketepatan waktu pelaporan keuangan pada perusahaan manufaktur yang terdaftar di Bursa Efek Indonesia tahun 2016-2019. Hal ini dibuktikan dengan uji hasil hipotesis pada profitabilitas dengan angka signifikan sebesar $0,001<0,05$, bahwa hipotesis kelima diterima.

\section{Referensi}

[1] I. M. Ibadin, F. Izedonmi, and P. O. Ibadin, "The association between selected corporate governance attributes, company attributes and timeliness of financial reporting in Nigeria," Res. J. Financ. Account., vol. 3, no. 9, pp. 137-144, 2012, [Online]. Available: http://www.iiste.org/Journals/index.php/RJFA/article/view/3159.

[2] A. A. Oussii and B. N. Taktak, "Audit committee effectiveness and financial reporting timeliness: The case of Tunisian listed companies," African J. Econ. Manag. Stud., vol. 9,

JURNAL ILMIAH KOMPUTERISASI AKUNTANSI Vol. 14, No. 2, Desember $2021: 265-274$ 
no. 1, pp. 34-55, 2018, doi: 10.1108/AJEMS-11-2016-0163.

[3] D. N. Pradipta and B. Suryono, "Analisis Faktor-Faktor Yang Mempengaruhi Ketepatan Waktu Pelaporan Keuangan,” J. Ilmu Dan Ris. Akunt., vol. 6, no. 1, pp. 1-17, 2017.

[4] F. Kurniawan and T. D. Widajantir, "Pengaruh Leverage, Profitabilitas, Dan Ukuran Perusahaan Terhadap Ketepatan Waktu Pelaporan Keuangan Pada Perusahaan Keuangan Yang Terdaftar Di Bursa Efek Indonesia Periode 2015-2019," J. Ilm. Komputerisasi Akunt., vol. 14, no. 1, pp. 84-91, 2021.

[5] Tj. L. Abernathy, B. Beyer, A. Masli, and C. Stefaniak, "How the Source of Audit Committee Accounting Expertise Influences Financial Reporting Timeliness," Curr. Issues Audit., vol. 9, no. 1, pp. 1395-1435, 2015.

[6] M. Harnida, "Pengaruh Mekanisme Corporate Governance terhadap ketepatan waktu penyampaian laporan keuangan (studi empiris pada perusahaan publik yang terdaftar di bursa efek indonesia)," Jsai, vol. 2, no. 1, pp. 25-36, 2015.

[7] M. Rivandi and M. M. Gea, "Pengaruh Mekanisme Corporate Governance Terhadap Ketepatan Waktu Pelaporan Keuangan (Studi Empiris Pada Perusahaan Perbankan Milik Pemerintah Pusat)," J. Akunt. dan Pajak, vol. 19, no. 1, p. 1, 2018, doi: 10.29040/jap.v19i1.167.

[8] R. D. Ardanty and Sofie, "Pengaruh Mekanisme Corporate Governance Terhadap Ketepatan Waktu Pelaporan Keuangan pada Perusahaan Manufaktur yang Terdaftar di BEI,” J. Akunt. dan Keuang., no. 2012, pp. 1-25, 2016.

[9] S. A. Dwiyani, I. D. N. Badera, and I. P. Sudan, "Faktor-Faktor Yang Mempengaruhi Ketepatwaktuan Penyajian Laporan Keuangan," E-Jurnal Ekon. dan Bisnis Univ. Udayana, vol. 4, pp. 1451-1480, 2017.

[10] R. Amelia, "Pengaruh Mekanisme Corporate Governance Terhadap Ketepatan Waktu Penyampaian Laporan Keuangan Perusahaan," Media Ris. Akunt., vol. 3, no. 2, p. Hal. 4365, 2013.

[11] H. O. Aifuwa, S. Musa, and N. O. Gold, "Audit Committee Attributes and Timeliness of Corporate Financial Reporting in Nigeria," Account. Financ., vol. 37, no. 2(88), pp. 114124, 2020, doi: 10.33146/2307-9878-2020-2(88)-114-124.

[12] C. Ghafran and S. Yasmin, "Audit committee chair and financial reporting timeliness: A focus on financial, experiential and monitoring expertise," Int. J. Audit., vol. 22, no. 1, pp. 13-24, 2018, doi: 10.1111/ijau.12101.

[13] U. Rahmatia, H. K. Ts, and S. Nurlela, "Pengaruh Mekanisme Good Corporate Governance Terhadap Ketepatan Waktu Penyampaian Pelaporan Keuangan," J. EMBA J. Ris. Ekon. Manajemen, Bisnis dan Akunt., vol. 8, no. 1, 2020, doi: 10.35794/emba.v8i1.27856.

[14] I. M. D. M. Sanjaya and N. gusti P. Wirawati, "Analisis Faktor-Faktor Yang Mempengaruhi Ketepatan Waktu Pelaporan Keuangan Pada Perusahaan Manufaktur Yang

Analisis Determinan Ketepatan Waktu Pelaporan Keuangan Perusahaan Manufaktur (Adila Ayu 
Terdaftar Di Bursa Efek Indonesia," E-Jurnal Akunt. Univ. Udayana, vol. 15, no. 1, pp. 126, 2016, doi: 10.47663/abep.v6i1.47.

[15] I. B. K. Y. Mahendra and I. N. W. A. Putra, "Pengaruh Komisaris Independen, Kepemilikan Institusional, Profitabilitas, Likuiditas, dan Ukuran Perusahaan terhadap Ketepatwaktuan," E-Jurnal Akunt. Univ. Udayana, vol. 9, no. 1, pp. 180-199, 2014.

[16] F. Azhari and M. Nuryatno, "Peran Opini Audit Sebagai Pemoderasi Pengaruh Profitabilitas, Ukuran Perusahaan, Kepemilikan Institusional, Dan Komite Audit Terhadap Ketepatan Waktu Pelaporan Keuangan," J. Magister Akunt. Trisakti, vol. 7, no. 1, p. 61, 2020, doi: 10.25105/jmat.v7i1.6337.

[17] A. F. Lumbantoruan and S. B. Siahaan, "Pengaruh Profitabilitas, LIkuiditas, Ukuran Perusahaan, Umur Perusahaan, Reputasi KAP dan Kepemilikan Manajerial Terhadap Ketepatan Waktu Pelaporan Keuangan Pada Perusahaan Otomotif dan Komponen Yang Terdaftar di Bursa Efek Indonesia Periode 2012-2016,” J. Ilm. Simantek, vol. 2, no. 3, pp. 66-80, 2018.

[18] A. A. Dufrisella and E. S. Utami, "PENGARUH GOOD CORPORATE GOVERNANCE TERHADAP KETEPATAN WAKTU PENYAMPAIAN LAPORAN KEUANGAN (Studi Kasus Pada Perusahaan Manufaktur Di BEI)," J. Ris. Akunt. Mercu Buana, vol. 6, no. 1, p. 50, 2020, doi: 10.26486/jramb.v6i1.1195. 